\title{
Control of growth and flowering of chrysanthemum (Dendranthema $x$ grandiflorum Kitam.) using day length extension and Red Light Night Break
}

\author{
Million Haile Belay ${ }^{1}$ (D), Hussien Mohammed Beshir ${ }^{2 *}$ (D), Meseret Tesema Terfa ${ }^{2}$ (D), Amsalu Gobena Roro ${ }^{2}$ (D) \\ ${ }^{1}$ Debark University, Department of Horticulture, Debark, Ethiopia. \\ ${ }^{2}$ Hawassa University, School of Plant and Horticultural Sciences, Hawassa, Ethiopia.
}

\begin{abstract}
In tropical areas, since the day length (DL) is shorter than the critical DL for chrysanthemum (Dendranthema $x$ grandiflorum Kitam.), chrysanthemum flowers before reaching the required stem length(SL) for cut flower. Two experiments were conducted with the aim of determining critical DL for vegetative growth of chrysanthemum genotype; to attain a required SL and promote vegetative growth of chrysanthemum using night break (NB) with red light for spray type of chrysanthemum. In the first experiment, DL was extended by one, two, and three hours using white fluorescent light (WL) after sunset. In the second experiment, red light (RL) was applied at the middle of the night for 15, 30, or 45 minutes to break the night. The experiments were laid out in completely randomized design with four replications. The results indicated DL extension with WL and RL night breaks had significant effect on vegetative characters and biomass yield. Similarly, flower bud initiation, coloring and blooming were significantly affected. NB using RL had a significant effect on flower diameter. The three hours DL extension (12+3 hours) totally inhibited flowering of chrysanthemum genotype, which can be considered a critical DL for Hawa1. NB with RL for 15, 30, or 45 minutes effectively inhibited flowering of chrysanthemum. In conclusion, breaking the night with RL at the middle of the night for 15 minutes with small amount of intensity $\left(9.42 \mu \mathrm{molm}^{-2} \mathrm{~s}^{-1}\right)$ is enough to inhibit flowering and promote stem elongation of chrysanthemum Hawal.
\end{abstract}

Keywords: flower initiation; night break; phytochrome; red light.

\section{Resumo}

Controle de crescimento e florescimento de crisântemo (Dendranthema x grandiflorum Kitam.) utilizando complementação do tamanho do dia e quebra da noite com luz vermelha

Em áreas tropicais, como o comprimento do dia (CD) é menor do que o CD crítico para o crisântemo (Dendranthema x grandiflorum Kitam.), o crisântemo floresce antes de atingir o tamanho de haste $(\mathrm{TH})$ necessário para a flor de corte. Dois experimentos foram conduzidos com o objetivo de determinar o CD crítico para que o crescimento vegetativo do crisântemo cultive 'Hawal' do tipo spray e para atingir um TH necessário e promover o crescimento vegetativo do crisântemo usando quebra do nictoperíodo $(\mathrm{QB})$ com luz vermelha. No primeiro experimento, o CD foi estendido em uma, duas e três horas usando luz fluorescente branca (LFB) após o pôr do sol. No segundo experimento, a luz vermelha (LV) foi aplicada no meio da noite por 15, 30 e45 minutos para quebrar a noite. Os experimentos foram dispostos em delineamento inteiramente casualizado com quatro repetições. Os resultados indicaram que a extensão do CD com pausas noturnas LFB e LV teve efeito significativo sobre os caracteres vegetativos e produção de biomassa. Da mesma forma, a iniciação, coloração e florescimento do botão floral foram significativamente afetados. QB usando LV teve um efeito significativo no diâmetro da flor. A extensão de DL de três horas (12+3 horas) inibiu totalmente o florescimento do genótipo de crisântemo, o que pode ser considerado um CD crítico para 'Hawa1'. QB com LV por 15, 30 e 45 minutos inibiu efetivamente o florescimento do crisântemo. Em conclusão, interromper a noite por 15 minutos com LV com pequena intensidade $\left(9,42 \mu \mathrm{molm}^{-2} \mathrm{~s}^{-1}\right)$ é suficiente para inibir o florescimento e promover o alongamento do caule do crisântemo 'Hawa1'.

Palavras-chave: iniciação da flor; quebra da noite; fitocromo; luz vermelha.

\section{Introduction}

In most plant species, the length of the light phase, the photoperiod, determines flowering time. Long day (LD) plants like Hordeum vulgare flower in response to increasing day length; whereas short-day (SD) plants include sorghum and chrysanthemum; they flower in responses to night length (Pearce et al., 2017). Chrysanthemum is a globally important

*Corresponding author: muzeyenyesuf2003@yahoo.com 
ornamental plant, a typical SD plant, which flowers when nights are longer than a critical minimum length.

Light treatment demonstration on different plant species revealed that night breaking with red light was shown to be the most effective in inhibiting flowering; and the effect was reversed when treated with FR-light (Zhang and Runkle, 2019). Red to far-red light-absorbing phytochromes have long been considered important photoperiodic photoreceptors. Recent molecular genetic investigations have revealed that phytochromes are essential for photoperiodic flowering in most short day plants species (Park and Jeong, 2019). Similarly, previous report also indicated that Red and Far-Red lights, which are absorbed by the phytochrome system, are important in controlling photomorphogenesis and flowering (Legris et al., 2019). Phytochromes are a photoreceptor pigment that if found in plants regulate plant development, physiology, and metabolism, based on circadian, seasonal, and positional information (Lymperopoulos et al., 2018).

Phytochrome is encoded by a multigene family phytochrome A-E (PHYA-E), which was for the first time identified from Arabidopsis. In higher plants, phytochromes are the major photoreceptors for perceiving the red $(\mathrm{R})$ and far-red (FR) spectrums $(600-750 \mathrm{~nm})$ of the terrestrial light, and play a fundamental role in regulating almost every aspect of plant growth and development (Krahmer et al., 2018).

In dark grown seedlings, PHYA is the most abundant phytochrome, although it is rapidly degraded upon exposure to light (Courbier and Pierik, 2019). In sunlight, however, PHYB is the most abundant phytochrome due to PHYA degradation (Courbier and Pierik, 2019). PHYA regulates seed germination and seedling morphogenesis (Sheerin and Hiltbrunner, 2017). According to the conclusion of Seaton et al. (2018), phytochrome $\mathrm{A}$ is involved in the detection of day length, whereas phytochromes B, D, and E all play a role in the perception of R:FR ratio signals. Interruption of the dark period during short days (long nights) with red light stops the reversion of Pfr730 to Pr660 and converts Pr660 into Pfr730. This prevents the level of Pfr730 from dropping below the critical Pfr730 level and, therefore, inhibits flowering in short-day plants and promotes flowering in long-day plants (Mer and Attri, 2015). A phytochrome photo equilibrium ( $\mathrm{Pfr} / \mathrm{Pr}+\mathrm{Pfr}$ or $\mathrm{Pfr} / \mathrm{P})$ is established depending on the quality of light. Where a high $\mathrm{R}: F R$ ratio creates high $\mathrm{Pfr} / \mathrm{P}$ and a low R: FR ratio creates low Pfr/P (Mer and Attri, 2015; Travlos et al., 2020).

Chrysanthemum is a short-day plant, which flowers when the night length is longer than a critical length. Using artificial light to increase day length is a common practice in protected horticulture production. As a tropical climate in Ethiopia, there is ample radiation for photosynthesis, biomass accumulation, and early flower initiation, hence inhibiting stem elongation. When Chrysanthemum is produced in tropics, it initiates flowers before attaining standard commercial stem length as a short-day plant. To produce commercially acceptable cut flower stem length and balance flowering time by manipulating growth, climate is a common practice. However, in tropical chrysanthemum production, this is rarely practiced, especially in Ethiopia. In this study we hypothesized that in tropical greenhouse production, where there is ample irradiance and high temperature, Chrysanthemum with longer stem and early flowering can be produced when the day length is extended beyond a minimum critical day length or interrupt the long nights. Therefore, the present study was conducted with the objective of determining the critical day length at tropical condition around Equator and to attain the commercially acceptable stem length for cut flower through either extending the day length, by using WL, or interrupting the night, by using low-intensity RL with shorter time of exposure.

\section{Material and Methods}

\section{Site description}

The experiments were conducted from November 18, 2016 to March 9, 2017; and from February 18, 2017 to May 9, 2017, in Hawassa University, College of Agriculture, which is located at latitude $7^{\circ} 4^{\prime} \mathrm{N}$ and longitude $38^{\circ} 31^{\prime} \mathrm{E}$ (Beshir et al., 2016). This is a hot to warm sub-moist humid climate zone with warmer temperature, especially during the dry season. It has a longer growing season and a less definitive pattern of rain fall during the growing season (Beshir et al., 2016). The altitude of Hawassa is about 1,700 m.a.s.l., and the mean Annual rain fall is $962 \mathrm{~mm}$. It is a mid-highland area in the Rift Valley zone. The soil is loam characterized by slightly acidic pH (Beshir et al., 2016).

\section{General experimental procedure}

Photoequilibrium was calculated using a formula phytochrome photostationary state $(\mathrm{PPS})=\mathrm{Pr} / \mathrm{Pr}+\mathrm{Pfr}$ (Sager et al., 1988) for both white and red light relative photon irradiance $\left(\mu \mathrm{molm}^{-2} \mathrm{~s}^{-1}\right)$. Sager et al. (1988) measured the spectral absorptance of PR and PFR forms, and expressed the results as phytochrome photochemical cross-sections, represented as $\sigma \mathrm{r}$ and $\sigma \mathrm{fr}$, respectively. This method was developed to estimate PPS using the complete spectrum of the plants' light environment instead of simply calculating the red to far-red ratio.

Then, PPS is calculated as follows (Equation 1):

$$
\text { PPS }=\frac{\sum_{300}^{800} \mathrm{~N}(\lambda) \sigma r(\lambda)}{\sum_{300}^{800} \mathrm{~N}(\lambda) \sigma r(\lambda)+\mathrm{N}(\lambda) \sigma \mathrm{fr}(\lambda),}
$$

Where:

$N(\lambda)=$ the measured spectral photon flux for wavelength $\lambda$ over the range of $300 \mathrm{~nm}$ and $800 \mathrm{~nm}$.

PPS describes the relative amount of active phytochrome in proportion to total phytochrome. Accordingly, phytochrome photostationary state value for white fluorescent light and red fluorescent light were 0.83 and 0.85 ; respectively, with only a $2 \%$ difference. From this calculated phytochrome stationary state, the result indicated that $83 \%$ was inactive isomer (inactive phytochrome), which is $\mathrm{PR}$, and $17 \%$ was $\mathrm{PFR}$, which is active isomer for broad spectrum white lamp, whereas for red lamp, narrow spectrum $85 \%$ was inactive isomer (inactive phytochrome), which is $\mathrm{PR}$, and $15 \%$ was active isomer, which is PFR. 
Experiment I: Determining critical day length and improving growth performance of chrysanthemum genotype (Hawa1) by using supplemental light under Tropical conditions

This experiment involved four treatments. Treatment one: natural day (without artificial light-Control); Treatment two: with day length extension of one hour (day time+1 $\mathrm{hr}$ light=13 hr light period); Treatment three: day length extension of two hours (day time $+2 \mathrm{hr}$ light $=14 \mathrm{hr}$ light period); and Treatment four: day length extension of three hours (day time $+3 \mathrm{hr}$ light=15 hr light period) at the end of the day using white fluorescent lamp (Figure 1A). The experiment was laid out in completely randomized design (CRD) with four replications. Four pots were used for each treatment and replications. Two rooted cuttings were transplanted per pot. The seedlings height at this stage was about $10 \mathrm{~cm}$, with four to five leaves.

The photoperiod duration in Hawassa during experiment I was 12 hours light/12 hours night on average. As result, it was supplemented by artificial light with white fluorescent lamp after sunset as per treatment. Whitefluorescent lamps were hanged $90 \mathrm{~cm}$ above the ground and $72 \mathrm{~cm}$ above the pots (Stack et al., 1998). The lamps were fixed on wood bar stretched across the experimental pots supported by wood frame to provide the supplemental light. The light intensity (PAR) of the supplemental light used as a day extension above the plant canopy was ranged between 5.51-25.6 $\mu \mathrm{molm}^{-2} \mathrm{~s}^{-1}$, but, on average, each plant

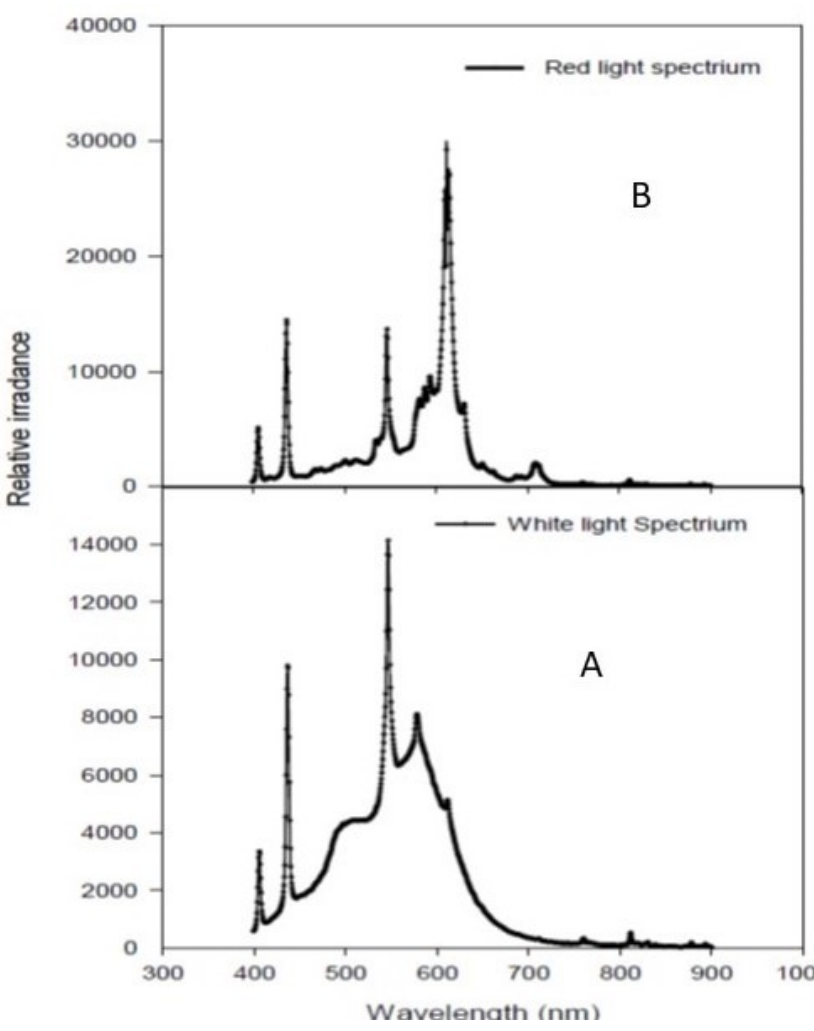

Figure 1. (A) Red fluorescent light used to break the night in experiment II. (B) Intensity of white fluorescent light used to extend the day length in experiment I. The light intensity was measured with Skye, SpectroSense 2. received $13.36 \mu \mathrm{molm}^{-2} \mathrm{~s}^{-1}$. The lighting was controlled by timers (Outdoor timer, Model: ElM-832, Germany) set to switch on and off according to the treatments' duration. Black polyethylene sheet was stretched between adjacent treatments only during time of light application to block light contamination.

The experimental treatments were commenced five days after transplanting for the next 111 days until the treatment application was finished. After termination of day length treatment (111 days), the short day resumed and plants initiated flowers, depending on treatments.

Experiment II: Controlling flowering of chrysanthemum to attain a required plant height by using red light night break

For this experiment, red light (Figure 1B) was used to induce night break (NB) in the middle of the night. The treatments included Treatment one (Control, natural day); Treatment two (15 minutes red light flash (12:45 AM - 1:00 AM)); Treatment three (30 minutes red light flash (12:45 AM - 1:15 AM)); and Treatment four (45 minutes red light flash (12:45 AM - 1:30 AM)). These four treatments were laid out in CRD with three replications. Red light had been applied using red fluorescent lamp (YAXING, YZ40W T8), which was hanged horizontally at $90 \mathrm{~cm}$ height above the ground on the top of the plant (Stack et al., 1998). The red light was provided for specific treatment, and the other treatments were screened out using black plastic as blackout screens similar to experiment I. The light intensity (PAR) of the supplemental light above the plant canopy ranged between $3.78-18.29 \mu \mathrm{molm}^{-2} \mathrm{~s}^{-1}$, but, on average, each plant received $9.42 \mu \mathrm{molm}^{-2} \mathrm{~s}^{-1}$. Timers (Outdoor timer, Model: ElM-832, Germany) were used to control night-break light duration. The red-light night break for this experiment lasted 80 days (started when rooted seedlings reached $10 \mathrm{~cm}$ in height, with four to five leaves). Therefore, plants were exposed to night break conditions and followed by normal condition (natural short day) period up to harvesting. After termination of red-light treatment, the short day resumed, and plants initiated flowering, depending on treatments.

\section{General procedure for data collection}

\section{Flower phenology}

Days to flower bud initiation was measured as the average number of days from transplanting to $50 \%$ of the appearance of flower buds. Days to flower bud coloring (flower bud break stage) was recorded as the average number of days from transplanting to $50 \%$ of the appearance of the color on flower buds. Days to flower bud blooming was taken as the average number of days from transplanting to $50 \%$ of the complete (full) opening of the flower.

Days to flower bud initiation after light treatments (night break) termination (stopped) was recorded as the average number of days taken after red light NB was terminated to $50 \%$ of the appearance of the flower buds. Days to flower bud coloring after light treatments (night break) termination was taken as the average number of days taken from the NB application termination to $50 \%$ of the 
appearance of the color on flower buds. Days to flower bud blooming after light treatments termination was recorded the average number of days taken after light supplement finished to $50 \%$ of the complete opening of the flower.

\section{Flower characters}

Number of flowers was recorded as all flowers appeared on main stalk, and side branches of one plant in each of the four pots were counted and were averaged per plant. The flower diameter was measured from randomly selected four plants in each treatment. The measurements were carried out when the plants were at full bloom, using a ruler.

\section{Vegetative characters}

Number of leaves, nodes, and branches per plant were recorded from all randomly selected four plants per replication and then averaged per plant. Plant height, stem diameter, and internode length were measured on four randomly selected plants, using a ruler. The leaf areas of four randomly selected plants were measured after flowering using leaf area meter (LI-3100, Lincoln, Nebraska USA).

\section{Aboveground biomass}

The above ground fresh biomass was measured, immediately after harvest from four randomly selected plants and then averaged per plant. The above ground dry biomass of four randomly selected plants were measured after plant materials were dried in an oven at $70^{\circ} \mathrm{C}$ until constant weight was obtained, using a sensitive balance.

\section{Data analysis}

The collected data were subjected to Analysis of variance (ANOVA) using proc GLM model of SAS (9.0) and means' values were compared using Least Significance Difference (LSD) at $\mathrm{P}<0.05$ level.

\section{RESULTS}

Experiment I: determining critical day length and improving growth performance of chrysanthemum genotype (Hawa1), using supplemental light under Hawassa conditions

\section{Phenology of flowers}

Extending day light using white light had significant $(\mathrm{P}<0.0001)$ effect on all parameters of phenology of flowers, such as days to flower bud initiation, days to flower bud coloring, and days to flower bud blooming (Table 1).

Day light extension in one or two hours did not inhibit flower initiation during the treatment period (Figure 2). However, day light extension in three hours totally inhibited flower initiation (Figure 2) during the treatment. Regardless of total flowering inhibition, the study showed that day light extension by one and two hours (day time +1 hour and day time +2 hours) delayed both flower initiation and development as compared to the control (day time +0 hours) (Table 1). This indicated that increasing day length by a certain hour $(12+1,12+2)$ can delay flowering of chrysanthemum even before the critical day length. The amount of delay was proportional to the number of extended day light hours considered in the treatments (Table 1 and Figure 2). This indicates the longer the number of hours used to extend that day, the more it delays flowering even before the critical day length for inhibition of flower initiation. The number of days from coloring to flower blooming and/or from flower initiation to booming

Table 1. Effect of day length extension (DLE) on phenology of chrysanthemum after 111 days of DLE*.

\begin{tabular}{|l|c|c|c|c|c|}
\hline $\begin{array}{l}\text { Day length } \\
\text { extension (hours) }\end{array}$ & $\begin{array}{c}\text { Days to flower } \\
\text { initiation }\end{array}$ & $\begin{array}{c}\text { Days to flower } \\
\text { coloring }\end{array}$ & $\begin{array}{c}\text { Days to flower } \\
\text { blooming }\end{array}$ & $\begin{array}{c}\text { Days from initiation } \\
\text { to flower blooming }\end{array}$ & $\begin{array}{c}\text { Days from coloring } \\
\text { to flower blooming }\end{array}$ \\
\hline $12+0$ & $67 \mathrm{~d}$ & $82 \mathrm{~d}$ & $92 \mathrm{~d}$ & $25 \mathrm{~b}$ & $10 \mathrm{~b}$ \\
\hline $12+1$ & $80 \mathrm{c}$ & $93 \mathrm{c}$ & $105 \mathrm{c}$ & $25 \mathrm{~b}$ & $12 \mathrm{~b}$ \\
\hline $12+2$ & $132 \mathrm{~b}$ & $153 \mathrm{~b}$ & $191 \mathrm{~b}$ & $59 \mathrm{a}$ & $38 \mathrm{a}$ \\
\hline $12+3$ & $182 \mathrm{a}$ & $192 \mathrm{a}$ & $207 \mathrm{a}$ & $25 \mathrm{~b}$ & $15 \mathrm{~b}$ \\
\hline LSD & 1.475 & 1.977 & 1.604 & 2.7 & 5.4 \\
\hline CV\% & 0.832 & 0.985 & 0.699 & 0.89 & 1.96 \\
\hline
\end{tabular}

*Means with the same letter are not significantly different; LSD (0.05): least significance difference at $5 \%$ level, CV\%: coefficient of variance in percent.
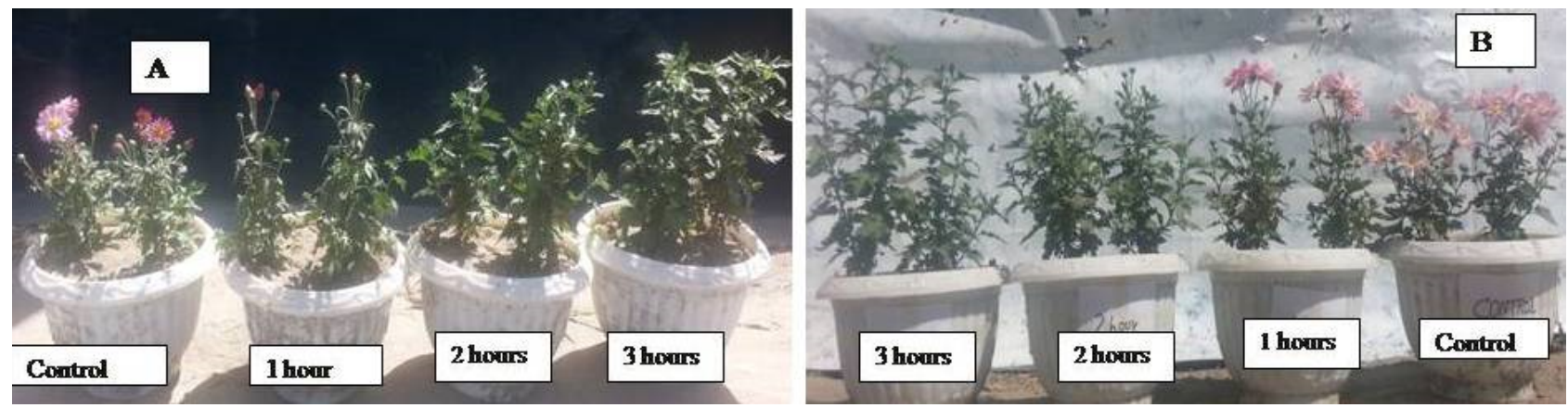

Figure 2. Phenology chrysanthemum genotype (Hawa1) affected by different day light extensions. The picture was taken at (A) day 45 and at (B) day 80 after transplanting. 
at $12+2$ hours was different from the other treatments (Table 1). This is because at $12+2$ hours, plant initiate few flowers and show color, but this day length was not enough to bloom. Therefore, plants in this treatment should wait until the natural short day resumes to them to bloom.

\section{Flower number and flower diameter}

Day light extension had a significant $(\mathrm{P}<0.0001)$ impact on total numbers of flowers. However, day length extension had no significant $(\mathrm{P}>0.1799)$ effect on flower diameters.

The highest numbers of flowers were recorded when day light was extended in three hours (Table 2). This might be mainly due to the treatment, which induced more source (leaf area) area and accumulate more carbohydrate, which help in flower (Sink) induction.

Effect of day light extension on the Vegetative growth of chrysanthemum

Day light extension using white fluorescent light had significant $(\mathrm{P}<0.0001)$ effect on number of leaves, number of nodes, stem diameter, plant height, and leaf area. Additionally, internode length and number of branches were significantly $(\mathrm{P}<0.01)$ affected by day light extension. Analysis of variance further revealed that day light hour extension had significant $(\mathrm{P}<0.0001)$ influence on fresh and dry weight $(\mathrm{P}<0.05)$ of shoot of chrysanthemum. Day light extension for three hours resulted in the highest

Table 2. Effect of day length extension (DLE) on flower characters of chrysanthemum after 111 days of DLE*.

\begin{tabular}{|lcc|}
$\begin{array}{l}\text { Day length } \\
\text { extension (hours) }\end{array}$ & $\begin{array}{c}\text { Flower diameter } \\
\text { (cm) }\end{array}$ & $\begin{array}{c}\text { Total number of } \\
\text { flowers }\end{array}$ \\
\hline $12+0$ & 3.99 & $24.3 \mathrm{~b}$ \\
\hline $12+1$ & 3.71 & $30.7 \mathrm{~b}$ \\
\hline $12+2$ & 4.44 & $91.3 \mathrm{a}$ \\
\hline $12+3$ & 4.20 & $96.4 \mathrm{a}$ \\
\hline LSD & $\mathrm{ns}$ & 10.79 \\
\hline CV\% & 11.0 & 11.5 \\
\hline
\end{tabular}

*Means with the same letter are not significantly different; LSD (0.05): least significance difference at $5 \%$ level; $\mathrm{CV} \%$ : coefficient of variation in percent; ns: non-significant. vegetative growth, which can secure sufficient stem length for commercial market (Table 3 ).

Experiment II: control of flowering of chrysanthemum to attain a required plant height using red light night break

\section{Phenology of flowers}

Analysis of variance revealed that there was a significant $(\mathrm{P}<0.0001)$ difference among the mean value of flowers phenology, such as days to flower initiation, days to flower coloring, and days to flower blooming, because of the application of red light as night break.

The result indicated that night break with red light for all the durations tested $(15,30$, and 45 minutes) totally inhibited flower initiation of chrysanthemum genotype (Figure 3). Only the control treatment (no night break) flowered before night break treatment was stopped. Chrysanthemum genotype subjected to night break started flower initiation only after the night break treatment was interrupted. However, when following the night break treatment with red light, flower initiation, flower coloring, and flower blooming vary with the duration of time (treatment) which the light was applied for night break (Table 4). This indicates that the length of red-light duration as night break had a carryover effect to induce the time for flower initiation and phenological changes.

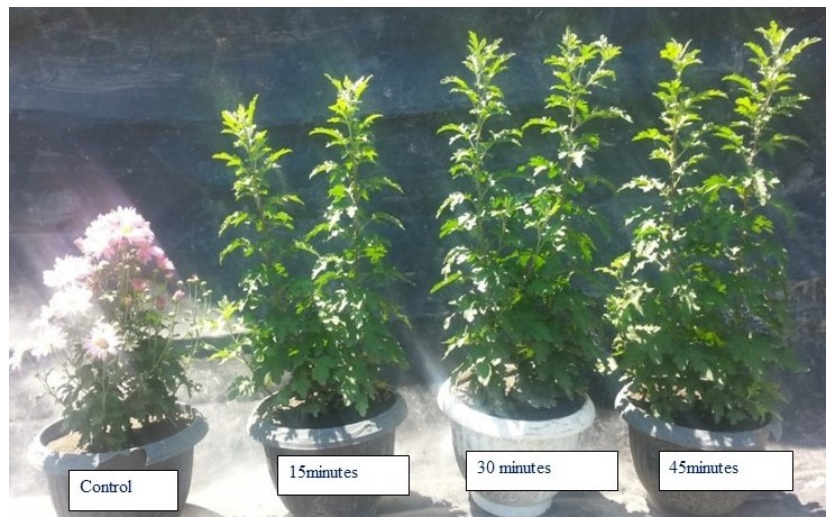

Figure 3. Chrysanthemum genotype affected by night breaks with red fluorescent light at 80 days.

Table 3. Effect of day length extension (DLE) on vegetative characters chrysanthemum after 111 days of DLE*.

\begin{tabular}{|c|c|c|c|c|c|c|c|c|c|}
\hline $\begin{array}{l}\text { Day } \\
\text { length } \\
\text { extension } \\
\text { (hours) }\end{array}$ & $\begin{array}{l}\text { Number } \\
\text { of leaves }\end{array}$ & $\begin{array}{c}\text { Number } \\
\text { of } \\
\text { branches }\end{array}$ & $\begin{array}{l}\text { Internode } \\
\text { length } \\
\text { (cm) }\end{array}$ & $\begin{array}{l}\text { Number } \\
\text { of nodes }\end{array}$ & $\begin{array}{c}\text { Stem } \\
\text { diameter } \\
(\mathrm{cm})\end{array}$ & $\begin{array}{c}\text { Plant } \\
\text { height } \\
(\mathrm{cm})\end{array}$ & $\begin{array}{c}\text { Leaves } \\
\text { area } \\
\left(\mathrm{cm}^{2}\right)\end{array}$ & $\begin{array}{c}\text { Shoot } \\
\text { fresh } \\
\text { weight } \\
\text { (g plant }^{-1} \text { ) }\end{array}$ & $\begin{array}{l}\text { Shoot dry } \\
\text { weight } \\
\left.\text { (g plant }^{-1}\right)\end{array}$ \\
\hline $12+0$ & $169.06 \mathrm{~d}$ & $21.13 \mathrm{ab}$ & $2.38 b$ & $20.19 \mathrm{c}$ & $1.00 \mathrm{~d}$ & $22.95 \mathrm{c}$ & $607.60 \mathrm{c}$ & $48.2 \mathrm{c}$ & $10.13 \mathrm{c}$ \\
\hline $12+1$ & $268.13 c$ & $18.63 b$ & $2.70 \mathrm{ab}$ & $19.72 \mathrm{c}$ & $1.18 \mathrm{c}$ & $22.66 \mathrm{c}$ & $635.46 c$ & $50.4 \mathrm{c}$ & $10.69 \mathrm{c}$ \\
\hline $12+2$ & $473.63 b$ & $17.63 b$ & $3.07 \mathrm{a}$ & $25.56 \mathrm{~b}$ & $1.38 \mathrm{~b}$ & $38.82 b$ & $1136.40 \mathrm{~b}$ & $140.3 b$ & $26.26 \mathrm{~b}$ \\
\hline $12+3$ & $659.31 \mathrm{a}$ & $24.88 \mathrm{a}$ & $3.01 \mathrm{a}$ & $39.81 \mathrm{a}$ & $1.59 \mathrm{a}$ & $50.30 \mathrm{a}$ & $1453.83 \mathrm{a}$ & $173.1 \mathrm{a}$ & $32.08 \mathrm{a}$ \\
\hline LSD & 76.51 & 3.79 & 0.42 & 2.55 & 0.17 & 2.97 & 174.87 & 7.40 & 1.70 \\
\hline $\mathrm{CV} \%$ & 12.65 & 11.95 & 9.69 & 6.29 & 8.52 & 5.72 & 11.84 & 4.7 & 5.6 \\
\hline
\end{tabular}

*Means with the same letter are not significantly different; LSD (0.05): least significance difference at $5 \%$ level; CV\%: coefficient of variation in percent; ns: non-significant. 
The result indicated that night break for 30 minutes resulted in the highest number of days from flower initiation to blooming, but the control treatment took the highest number of days from flower coloring to blooming (Table 4).

Even if breaking the night for 15 minutes inhibited flowering, plants flowered sooner when the night break was stopped (short day condition resumes) (Table 5).

The current study showed that breaking the night for different durations (15, 30, and 45 minutes) have a similar impact on the inhibition of flower initiation, which all of them totally inhibited (Figure 3). However, these variations in the duration of night break have different impacts among them for the time of flower initiation when night break treatments were ceased (no night break).

\section{Flower number and diameter}

Red light as night break had a significant $(\mathrm{P}<0.0002)$ effect on flower diameter. However, total numbers of flowers were not significantly ( $\mathrm{P}>0.1086)$ affected by red light night break. Night break had no significant effect on flower number, but reduced flower diameter (Table 6).

\section{Vegetative characters}

Analysis of variance demonstrated that red light as night break had a significant $(\mathrm{P}<0.0001)$ effect on growth parameters, such as number of leaves, internode length, number of node, plant height. Additionally, leaf area $(\mathrm{P}<0.0003)$ and stem diameter $(\mathrm{P}<0.05)$ were affected by red-light night break. However, red-light night break had no significant influence on number of branches $(\mathrm{P}>0.5710)$. Furthermore, a significant $(\mathrm{P}<0.0001)$ difference was observed on fresh and dry weight of shoot. Night break with red light significantly improved vegetative growth of chrysanthemum (Table 7). Night break with red light for 45 minute resulted in the longest stem length in the current experiment (Table 7).

\section{Discussion}

Chrysanthemum plants under three hours light extension initiated flowers only after the day length extension treatment was terminated. In fact, day light extension in two hours inhibited the development of the flowers on most of the branches in a plant in the treatment, but it did not inhibit the development of some flowers in the same treatment. Some of the flowers that were bloomed under two-hours light extension treatment were aborted before the light treatment was finished. This indicated that day light extension in two hours was not sufficient to inhibit flower initiation, but sufficiently inhibited the development of initiated flowers. Thus, extending the day length in three hours (day time +3 hours light $=15$ hours light period) can be taken as a minimum critical day length for inhibition of flowering for the tested chrysanthemum genotype (Hawal).

Table 4. Effect of night break (NB) on phenology of chrysanthemum after 80 days of NB*.

\begin{tabular}{|l|c|c|c|c|c|}
\hline $\begin{array}{l}\text { Night break } \\
\text { (minutes) }\end{array}$ & $\begin{array}{c}\text { Days to flower } \\
\text { initiation }\end{array}$ & $\begin{array}{c}\text { Days to flower } \\
\text { coloring }\end{array}$ & $\begin{array}{c}\text { Days to flower } \\
\text { blooming }\end{array}$ & $\begin{array}{c}\text { Days to flower } \\
\text { initiation to flower } \\
\text { blooming }\end{array}$ & $\begin{array}{c}\text { Days to flower } \\
\text { coloring to flower } \\
\text { blooming }\end{array}$ \\
\hline 0 & $62.00 \mathrm{~d}$ & $91.75 \mathrm{c}$ & $102.75 \mathrm{~d}$ & $29.00 \mathrm{~b}$ & $11 \mathrm{a}$ \\
\hline 15 & $133.75 \mathrm{c}$ & $159.25 \mathrm{~b}$ & $166.75 \mathrm{c}$ & $25.5 \mathrm{c}$ & $7 \mathrm{c}$ \\
\hline 30 & $136.00 \mathrm{~b}$ & $161.75 \mathrm{a}$ & $169.75 \mathrm{~b}$ & $33.75 \mathrm{a}$ & $8 \mathrm{bc}$ \\
\hline 45 & $141.7575 \mathrm{a}$ & $162.75 \mathrm{a}$ & $171.75 \mathrm{a}$ & $21.00 \mathrm{~d}$ & $9 \mathrm{~b}$ \\
\hline LSD & 1.218 & 1.334 & 1.475 & 1.5 & 1.35 \\
\hline CV\% & 0.668 & 0.602 & 0.627 & 0.781 & 0.692 \\
\hline
\end{tabular}

*Means in the same column followed by the same letters are not significantly different at $5 \%$ level of significant according to LSD test; LSD (0.05): least significant difference at $5 \%$ level; $\mathrm{CV} \%$ : coefficient of variation in percent.

Table 5. Effect of night break (NB) on phenology of chrysanthemum after 80 days of NB was ceased*.

\begin{tabular}{|l|c|c|c|}
\hline $\begin{array}{l}\text { Night break } \\
\text { (minutes) }\end{array}$ & $\begin{array}{c}\text { Days to } \\
\text { flower } \\
\text { initiation }\end{array}$ & $\begin{array}{c}\text { Days to } \\
\text { flower } \\
\text { coloring }\end{array}$ & $\begin{array}{c}\text { Days to } \\
\text { flower } \\
\text { blooming }\end{array}$ \\
\hline 15 & $17.5 \mathrm{c}$ & $42.75 \mathrm{~b}$ & $49.75 \mathrm{c}$ \\
\hline 30 & $20 \mathrm{~b}$ & $44.5 \mathrm{a}$ & $52.5 \mathrm{~b}$ \\
\hline 45 & $24.5 \mathrm{a}$ & $45.5 \mathrm{a}$ & $55.5 \mathrm{a}$ \\
\hline LSD & 1.83 & 1.16 & 1.16 \\
\hline CV\% & 5.51 & 1.64 & 1.38 \\
\hline
\end{tabular}

*Means in the same column followed by the same letters are not significantly different at $5 \%$ level of significant according to LSD test; LSD (0.05): least significant difference at level of 5\%; CV\%: coefficient of variation in percent.
Table 6. Effect of night break (NB) on chrysanthemum flower characters after 80 days of NB*.

\begin{tabular}{|l|c|c|}
\hline $\begin{array}{l}\text { Night break } \\
\text { (minutes) }\end{array}$ & $\begin{array}{c}\text { Flower diameter } \\
\text { (cm) }\end{array}$ & $\begin{array}{c}\text { Total number of } \\
\text { flowers }\end{array}$ \\
\hline 0 & $4.6 \mathrm{a}$ & 45.9 \\
\hline 15 & $3.8 \mathrm{~b}$ & 52.4 \\
\hline 30 & $3.4 \mathrm{c}$ & 58.0 \\
\hline 45 & $4.0 \mathrm{~b}$ & 52.4 \\
\hline LSD & 0.393 & $\mathrm{~ns}$ \\
\hline CV\% & 6.459 & 11.971 \\
\hline
\end{tabular}

*Means with the same letter are not significantly different; LSD (0.05): least significant difference at level of $5 \%$; $\mathrm{CV} \%$ : coefficient of variation in percent; ns: non-significant. 
Table 7. Effect of night break (NB) on vegetative characters after 80 days of NB*.

\begin{tabular}{|c|c|c|c|c|c|c|c|c|c|}
\hline $\begin{array}{l}\text { Night } \\
\text { break } \\
\text { (minute) }\end{array}$ & $\begin{array}{l}\text { Number } \\
\text { of leaves }\end{array}$ & $\begin{array}{c}\text { Number } \\
\text { of } \\
\text { branches }\end{array}$ & $\begin{array}{c}\text { Internode } \\
\text { length } \\
\text { (cm) }\end{array}$ & $\begin{array}{l}\text { Number } \\
\text { of nodes }\end{array}$ & $\begin{array}{c}\text { Stem } \\
\text { diameter } \\
(\mathbf{c m})\end{array}$ & $\begin{array}{c}\text { Plant } \\
\text { height } \\
(\mathrm{cm})\end{array}$ & $\begin{array}{c}\text { Leaves } \\
\text { area } \\
\left(\mathrm{cm}^{2}\right)\end{array}$ & $\begin{array}{c}\text { Shoot } \\
\text { fresh } \\
\text { weight } \\
\text { (g plant }^{-1} \text { ) }\end{array}$ & $\begin{array}{l}\text { Shoot dry } \\
\text { weight } \\
\left(\text { g plant }^{-1}\right)\end{array}$ \\
\hline 0 & $77.44 \mathrm{c}$ & 19.88 & $2.29 c$ & $21.63 b$ & $1.23 b$ & $29.72 c$ & $559.3 \mathrm{c}$ & $53.49 \mathrm{~d}$ & $14.85 \mathrm{c}$ \\
\hline 15 & $206.09 b$ & 18.59 & $4.55 b$ & $43.81 \mathrm{a}$ & $1.39 \mathrm{a}$ & $63.56 \mathrm{~b}$ & $911.8 \mathrm{~b}$ & $88.35 \mathrm{c}$ & $30.09 \mathrm{~b}$ \\
\hline 30 & $255.59 a$ & 18.44 & $5.25 \mathrm{a}$ & $42.06 \mathrm{a}$ & $1.35 \mathrm{a}$ & $59.91 \mathrm{~b}$ & $1,088.5 \mathrm{ab}$ & $100.13 b$ & $34.88 \mathrm{a}$ \\
\hline 45 & $255.16 a$ & 19.06 & $5.18 \mathrm{a}$ & $44.16 \mathrm{a}$ & $1.36 \mathrm{a}$ & $71.44 \mathrm{a}$ & $1,178.3 \mathrm{a}$ & $109.31 \mathrm{a}$ & $36.04 \mathrm{a}$ \\
\hline LSD & 24.67 & ns & 0.51 & 2.36 & 0.12 & 3.96 & 219.6 & 8.415 & 4.39 \\
\hline $\mathrm{CV} \%$ & 8.06 & 8.14 & 7.61 & 4.04 & 5.97 & 4.57 & 15.25 & 6.22 & 9.83 \\
\hline
\end{tabular}

*Means in the same column followed by the same letters are not significantly different at $5 \%$ level of significant according to LSD test; LSD (0.05): least significant difference at level 5\%; CV\%: coefficient of variation in percent; ns: non-significant.

Although the two experiments (day light extension at the end of the day, and breaking the night using red light) were conducted separately, successful inhibition of flowering was observed in both experiments. However, day light extension at the end of the day was effective when the duration of extension was three hours. Whereas, breaking the night with red light was effective for 15-minute night break. Day light hour extension is less effective as compared to red light night break. This may be because phytochromes exist predominantly in the Pfr form (in daylight condition) before entering dark conditions, which results in the suppression of genes involved in elongation growth (Cao et al., 2016). Additionally, end of day light has lower R:FR ratios, which stimulate stem elongation. Although white light has lower R:FR ratio, it may take longer to activate the genes responsible for stem elongation. Breaking the night with red light is more effective and impacted flowering even at 15 minute flashes. The duration of red-night breaks also increased their effect on chrysanthemum. In the current experiment, red fluorescent lamp has higher R:FR than the white one (Figure 1). This result agrees with Craig and Runkle (2013), who reported that light conditions having higher R:FR are more effective in inhibiting flowering than those of low R:FR light conditions.

Results herein showed that breaking the night with red fluorescent light can impact flowering in a short period of flash time, eliminating the need of waiting for the three hours day-light extension, just like observed in experiment I. The phytochrome photostationary state of white fluorescent lamp become as high as red light lamp due to high blue light portion (not only due to red light portion) and it was also absorbed by phytochrome system. With only a small portion of difference in phytochrome system (2\%) at low light intensity, the conversion of active phytochrome (Pr) to Pfr is higher under red lamp than white fluorescent lamp. Therefore, short flash of red light (15 minutes) was enough to inhibit flowering in chrysanthemum (Hawa1). This small difference in phytochrome system also exerted significant difference in flower features, such as flower diameter and number of flowers among treatments in red-light night break experiment. Red light is more effective at inhibiting flowering of short day plants (SDPs) because high red: far red of fluorescent light is sufficient to convert enough phytochrome into the Pfr form to inhibit flowering, even at low intensity and short duration (Craig and Runkle, 2013; Mer and Attri, 2015). Red-light night break was effective at inhibiting flower initiation in chrysanthemum. This was similarly revealed by the authors Hakuzan et al. (2016), who observed that chrysanthemum cultivars IwanoHakusen and Jimba were inhibited flowering. It has been shown that days to the first visible bud or inflorescence appearance was substantially delayed by night break with red light. Park et al. (2015) found total inhibition of flowering when the night was interrupted with red light. Thus, according to Schroeter-Zakrzewska et al. (2017) the growth of chrysanthemum was more significantly affected by light quality than by light intensity, and irradiation duration for stem elongation. The ratio of Pr to Pfr in a plant enables it to determine the length of day and night. Flowering of chrysanthemum plants was effectively inhibited due to high ratio of red to far red light (13.31) in the current experiment.

Although all red-light night break treatments (15, 30 , and 40 minutes) have similar flowering inhibitory effects, the durations of flowering after termination of the night breaks varies with the duration of night break in each of night-break treatments. The speed of reversion of vegetative growth to flowering after termination of bight break treatments varies with the durations of night break. In this experiment, the longer the night break treatment, the longer it takes to initiate flowering after termination of night break treatment. This might be due to the existence of high portion of blue to far red ratio in the red light florescent.

Light hour extension and night break affected vegetative growth differently. Night-break treatments using red light resulted in better vegetative growth than the plants subjected to day-light hour extension. The highest fresh plant biomass was obtained under day light hour extension than those treated with red light night break. However, the highest total dry biomasses were found when red light night break were used than those plants under light hour extension.

Breaking the night with red light for 45 minutes improved the vegetative features, except for the number of branches (Table 7). Breaking the night with red light for each of 30 and 45 minutes had a similar impact on 
the number of leaves and leaf area, fresh weight, total fresh weight, shoot dry weight and total dry biomass of chrysanthemum. Additionally, breaking the night with red light for each of 15, 30, and 45 minutes had a similar impact on stem diameter and number of node of chrysanthemum plants. High differences were observed between red light and control treatments in both fresh and dry weight measurements of chrysanthemum genotype. Longer durations of red-light night break (30 and 40 minutes) resulted in similar impact on the biomass production of chrysanthemum. Hence, it can be pointed out that duration of night break with the applied amount of light (PAR) in this experiment had significant effect on biomass production of chrysanthemum. The current result is in conformity with the findings of Kim et al. (2004), who reported that fresh weight, dry weight, and leaf area were greatest under fluorescent supplemental light.

Reports indicated that changes in light spectrum influence shoot elongation, leaf area and leaf thickness. The red to far red ratio induced responses are regulated through the phytochrome photostationary state (PPS) which is used as an indicator for the relative amount of active phytochrome (Legris et al., 2019). These particular phytochrome molecules are important for plants to establish a certain routine which is called circadian rhythm.

Kim et al. (2004) reported that greatest stem length was obtained under R and RFR, but the stem elongation was due to internode elongation, particularly, the third internode where elongation almost doubled the first internode elongation. However, Liao et al. (2014) reported that there was no significant relation between the red/far red ratio of night break light and internode length. Number of leaves, branching rate and total leaf area, plant dry weight, percentage dry matter were altered under different light qualities for chrysanthemum and poinsettia. Plant height was significantly longer in plants cultured under $\mathrm{R}-\mathrm{LEDs}(\mathrm{R}=100 \%)$ in kale, but showed no difference in basil (Naznin et al., 2019). It seems that stem elongation can be promoted or inhibited by different synergistic interactions between blue/red light receptors and phytochrome according to species (Naznin et al., 2019). At lettuce seedling stage, highest height growth rate was obtained under fluorescent plus red LED. Significant effect of R and RFR (red plus far-red LED) on stem elongation has been reported in tomatoes (Kalaitzoglou et al., 2019), whereas inhibition of shoot elongation was observed under red light in pepper (Naznin et al., 2019). It was reported that lettuce shoot growth under monochromic $\mathrm{R}$ was fragile due to excessive elongation. In the current study, red light night break resulted in strong stem, which depicted a significant effect on stem diameter of chrysanthemum.

\section{Conclusion}

Flowering of chrysanthemum was totally inhibited when the day length hour was extended by three hours under Hawassa conditions. The current experiment confirmed that 15 hours can be considered as a critical day length for chrysanthemum genotype (Hawa1) to remain vegetative as a short-day plant at tropical conditions, around Equator. The second experiment showed that breaking the night with red light at the middle of the night for 15 minutes totally inhibited chrysanthemum's flowering. Night break with red light for 15 minutes is enough to maintain vegetative growth and a commercially acceptable stem length is attained. In practice, horticulture using red light as night break saves time and energy through minimizing electric consumption. As a result, red light flash for 15 minutes can be recommended as night break in the middle of the night to inhibit flowering until the required stem length is attained.

\section{Author contribution}

MHB: conceptualization, research development, methodology, formal analysis, graphs and figures preparation, writing original draft, writing review and editing. HMB: conceptualization, methodology, formal analysis, writing original draft, writing review and editing. MTT: supervision, writing original draft, writing review and editing. AGR: resources, supervision, graphs and figures preparation.

\section{Acknowledgments}

Hawassa University is acknowledged for the fund in support of disciplinary research.

\section{References}

BESHIR, H.M.; BUECKERT, R.; TAR'AN, B. Effect of temporary drought at different developmental stages on snap bean pod quality and yield. African Crop Science Journal, v.24, n.3, p.317-330, 2016. https://doi. org/10.4314/acsj.v24i3.8

CAO, K.; CUI, L.; YE, L.; ZHOU, X.; BAO, E.; ZHAO, H.; ZOU, Z. Effects of Red Light night break treatment on growth and flowering of tomato plants. Frontiers in Plant Science, v.7, p.527, 2016. https://doi.org/10.3389/ fpls.2016.00527

COURBIER, S.; PIERIK, R. Canopy light quality modulates stress responses in plants. iScience, v.22, p.441452, 2019. https://doi.org/10.1016/j.isci.2019.11.035

CRAIG, D.S.; RUNKLE, E.S. A Moderate to high red to far-red light ratio from light-emitting diodes controls flowering of short-day plants. Journal of American Society of Horticultural Sciences, v.138, n.3, p.167-172, 2013. https://doi.org/10.21273/JASHS.138.3.167

HAKUZAN, R.; KOORIYAMAA, K.; KIDO, K. Effects of $\mathrm{R}$ and $\mathrm{R}+\mathrm{FR}$ irradiance as night break on floral initiation in Chrysanthemum. Horticulture Research, v.15, n.4, p.417424, 2016. 
KALAITZOGLOU, P.; VAN IEPEREN, W.; HARBINSON, J.; VAN DER MEER, M.; MARTINAKOS, S.; WEERHEIM, K.; NICOLE, C.C.S.; MARCELIS, L.F.M. Effects of continuous or end-of-day far-red light on tomato plant growth, morphology, light absorption, and fruit production. Frontiers in Plant Science, v.10, p.322, 2019. https://doi.org/10.3389/fpls.2019.00322

KIM, S.J.; HAHN, E.J.; HEO, J.W.; PAEK, K.Y. Effects of LEDs on net photosynthetic rate, growth and leaf stomata of chrysanthemum plantlets in vitro. Scientia Horticulturae, v.101, n.1-2, p.143-151, 2004. https://doi.org/10.1016/j. scienta.2003.10.003

KRAHMER, J.; GANPUDI, A.; ABBAS, A.; ROMANOWSKI, A.; HALLIDAY, K.J. Phytochrome, carbon sensing, metabolism, and plant growth plasticity1 [CC-BY]. Plant Physiology, v.176, n.2, p.1039-1048, 2018. https://doi.org/10.1104/pp.17.01437

LEGRIS, M.; INCE, Y.Ç.; FANKHAUSER, C. Molecular mechanisms underlying phytochrome-controlled morphogenesis in plants. Nature Communications, v.10, 5219, 2019. https://doi.org/10.1038/s41467-019-13045-0

LIAO, Y.; SUZUKI, K.; YU, W.; ZHUANG, D.; TAKAI, Y.; OGASAWARA, R.; SHIMAZU, T.; FUKUI, H. Nightbreak effect of LED light with different wavelengths on shoot elongation of Chrysanthemum morifolium Ramat 'Jimba' and 'Iwa no hakusen'. Environmental Control in Biology, v.52, n.1, p.51-55, 2014. https://doi.org/10.2525/ ecb.52.51

LYMPEROPOULOS, P.; MSANNE, J.; RABARA, R. Phytochrome and phytohormones: Working in tandem for plant growth and development. Frontiers in Plant Science, v.9, p.14, 1037, 2018. https://doi.org/10.3389/ fpls.2018.01037

MER, M.S.; ATTRI, B.L. Effect of photoperiod on flowering in ornamental annuals. Journal of Medicinal Plants Studies, v.3, n.4, part B, p.121-126, 2015.

NAZNIN, M.T.; LEFSRUD, M.; GRAVEL, V.; AZAD, O.K. Blue Light added with Red LEDs enhance growth characteristics, pigments content, and antioxidant capacity in lettuce, spinach, kale, basil, and sweet pepper in a controlled environment. Plants, v.8, n.4, p.93, 2019. https://doi.org/10.3390/plants8040093

PARK, Y.G.; JEONG, B.R. Night interruption light quality changes morphogenesis, flowering, and gene expression in Dendranthema grandiflorum. Horticulture, Environment, and Biotechnology, v.60, n.2, p.167-173, 2019. https://doi. org/10.1007/s13580-018-0114-Z
PARK, Y.G.; MUNEER, S.; JEONG, B.R. Morphogenesis, flowering, and gene expression of Dendranthema grandiflorum in response to shift in light quality of night interruption. International Journal of Molecular Science, v.16, n.7, p.16497-16513, 2015. https://doi.org/10.3390/ijms160716497

PEARCE, S.; SHAW, L.M.; LIN, H.; COTTER, J.D.; LI, C.; DUBCOVSKY, J. Night-break experiments shed light on the photoperiod1-mediated flowering. Plant Physiology, v.174, n.2, p.1139-1150, 2017. https://doi. org/10.1104/pp.17.00361

SAGER, J.C.; SMITH, W.O.; EDWARDS, J.L.; CYR, K.L. Photosynthetic efficiency and phytochrome photoequilibria determination using spectral data. American Society of Agricultural and Biological Engineers, v.31, n.6, p.18821889, 1988. https://doi.org/10.13031/2013.30952

SCHROETER-ZAKRZEWSKA， A.; KLEIBER, T.; ZAKRZEWSKI, P. The response of chrysanthemum (Chrysanthemum $x$ grandiflorum Ramat/Kitam) cv. Covington to a different range of fluorescent and LED light. Journal of Elementology, v.22, n.3, p.1015-1026, 2017. https://doi.org/10.5601/jelem.2017.22.1.1252

SEATON, D.D.; TOLEDO-ORTIZ, G.; GANPUDI, A.; KUBOT, A.; IMAIZUMI, T. HALLIDAY, K.J. Dawn and photoperiod sensing by phytochrome A. Proceeding of the National Academy of Sciences of the United States of America, v.115, n.41, p.10523-10528, 2018. https://doi. org/10.1073/pnas.1803398115

SHEERIN, D.J.; HILTBRUNNER, A. Molecular mechanisms and ecological function of far-red light signaling. Plant Cell Environment, v.40, n.11, p.25092529, 2017. https://doi.org/10.1111/pce.12915

STACK, P.A.; DRUMMOND, F.A.; STACK, L.B. Chrysanthemum flowering in a blue light supplemented long day maintained for biocontrol of Thrips. HortScience, v.33, p.4, p.710-715, 1998. https://doi.org/10.21273/ HORTSCI.33.4.710

TRAVLOS,I.;GAZOULIS,I.;KANATAS,P.;TSEKOURA, A.; ZANNOPOULOS, S.; PAPASTYLIANOU, P. Key FACTORS affecting weed seeds' germination, weed emergence, and their possible role for the efficacy of false seedbed technique as weed management practice, Frontiers in Agronomy, v.2, p.1-9, 2020. https://doi. org/10.3389/fagro.2020.00001

ZHANG, M.; RUNKLE, E.S. regulating flowering and extension growth of Poinsettia using red and far-red lightemitting diodes for end-of-day lighting. HortScience, v.54, n.2, p.323-327, 2019. https://doi.org/10.21273/HORTSCI13630-18 